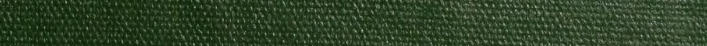

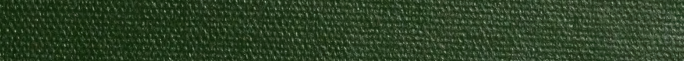
20. (1) W.

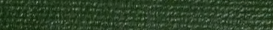
20. Fitis

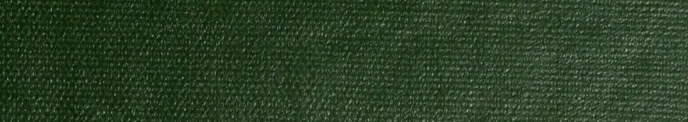

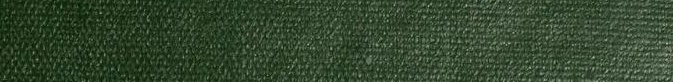

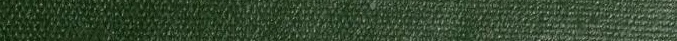
136.

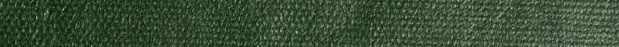

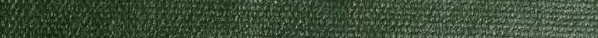

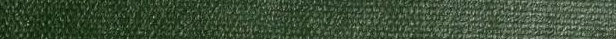




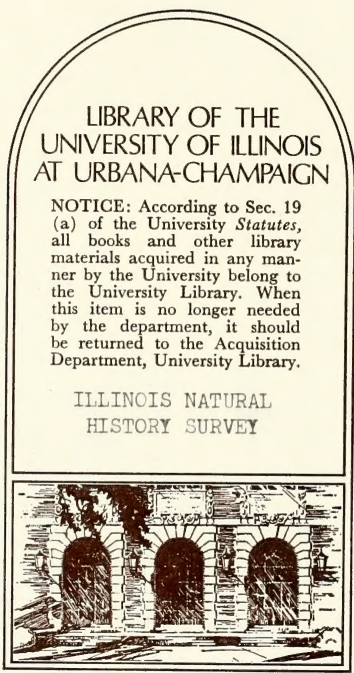






\section{THE LIFE HISTORIES OF Etheostoma olivaceum AND Etheostoma striatulum, TWO SPECIES OF DARTERS IN CENTRAL TENNESSEE}

Lawrence M. Page
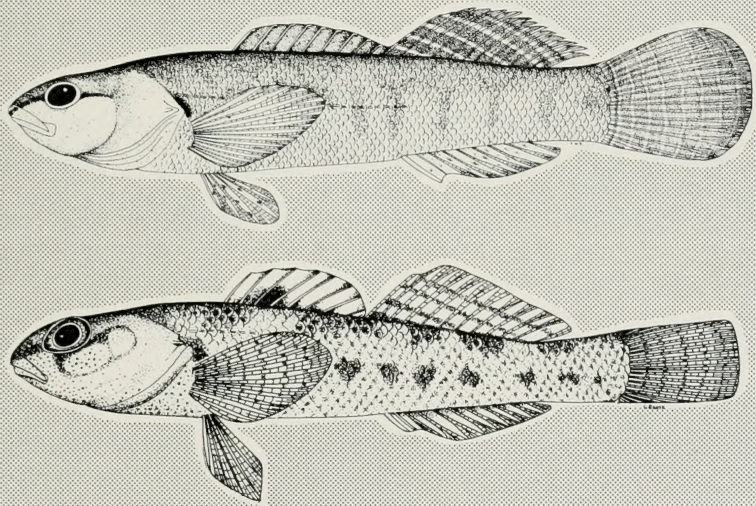

Biological Notes NNo. 113

State of Illinois

Illinois Institute of Natural Resources Natural History Survey Division
Illinois Natural History Survey

Urbana, Illinois August 1980 
The first paragraph on page 10 of The life histories of Etheostoma olivaceum and Etheostoma striatuium, two species of darters in central Tennessee should read as follows:

olivacerom in slab,pools, the preferred habitat, was found to be 4.04 individuals per $\mathrm{m}^{2}$. On 30 January 1979 densities of $E$. OLivaceum per $\mathrm{m}^{2}$ were: in slab pools, 8.07; in riffles, 1,79 ; in bedrock pools, 1.47 . On 30 January $1979,1.34 \mathrm{E}$. striatulim per $\mathrm{m}^{2}$ were found in the slab-rock portion (about one-fourth) of the large pool constituting the study area. 
$3 \times$ 


\section{THE LIFE HISTORIES OF ETHEOSTOMA OLIVACEUM AND ETHEOSTOMA STRIATULUM, TWO SPECIES OF DARTERS IN CENTRAL TENNESSEE}

The subgenus Catonotus, with 10 described species, is ecologically the best known group of darters. The inhabitation of slab-rock environments and the reproductive behavior, in which eggs are deposited on the undersides of stones and then guarded until hatching by the male, ecologically segregate Catonotus from all other darters. Other species of darters are found in slab-rock habitats but only certain species of Catonotus are restricted (as adults) to them. The habit of inverting and laying eggs on the undersides of stones is rare among darters and in addition to Catonotus is known only for the subgenus Boleosoma (known for three of the five species in the subgenus - Atz 1940, Winn 1958a, 1958b) and for Etheostoma (Nothonotus) maculatum (Raney \& Lachner 1939).

Life-history studies on the dirty darter, Etheostoma olivaceum, and the striated darter, Etheostoma striatulum, bring to seven the number of species of the subgenus Catonotus for which a substantial amount of lifehistory information is available. The other species are E. flabellare (Lake 1936, Winn 1958a, 1958b, Karr 1964), E. squamiceps (Page 1974), E. kennicotti (Page 1975a), E. smithi (Page \& Burr 1976), and E. barbouri (Flynn \& Hoyt 1979).

E. olivaceum is limited in distribution (Fig. 1) to tributaries of the lower Caney Fork (Cumberland River system) and nearby small direct tributaries of the Cumberland River in central Tennessee (Braasch \& Page 1979). Within this small area the species is abundant. E. striatulum occurs (Fig. 1) only in the upper Duck River system in Bedford, Marshall, and Maury counties in central Tennessee (Page \& Braasch 1977) and is generally uncommon.

I am indebted to Brooks M. Burr, Richard L. Mayden, and Michael A. Morris, all of Southern Illinois University at Carbondale, for aid in collecting specimens; to Richard L. Mayden, Edward A. Lisowski, Liane B. Suloway, John K. Bouseman, and Donald W. Webb, all now or formerly of the Illinois Natural History Survey, for assisting with laboratory analyses; and to David F. Oetinger, Houghton College, for identification of internal parasites. Cover illustrations were done by Craig W. Ronto. Assistance in preparing other illustrations was provided by Illinois Natural History Survey Illustrator

This paper is published by authority of the State of Illinois, and is a contribution from the Section of Faunistic Surveys and Insect Identification Taxonomist at the Survey. The publication was funded. Page is an Associate Foundation Grant DEB 76-15542.
Lloyd LeMere and Survey Photographer Larry Farlow. The manuscript was typed by Bernice P. Sweeney and edited for publication by Shirley McClellan, Assistant Technical Editor at the Survey. Dr. Herbert Boschung, University of Alabama, served as guest reviewer. This study was supported by National Science Foundation grant DEB 76-15542.

\section{STUDY AREAS AND METHODS}

Brush Creek, at the town of Brush Creek in Smith County, Tennessee (Fig. 2), is a spring-fed, direct tributary of Caney Fork and supports a large population of E. olivaceum. Other fishes present, in approximate order of abundance are Etheostoma atripinne, Pimephales notatus, Notropis species (cf. heterolepis), Cottus carolinae, N. telescopus, Fundulus catenatus, Campostoma anomalum, Hypentelium nigricans, Micropterus dolomieui, Phoxinus erythrogaster, $N$. ardens, Lepomis megalotis, L. cyanellus, L. macrochirus, E. flabellare, and Ictalurus melas.

At the study area, Brush Creek averaged approximately $6 \mathrm{~m}$ wide and was rarely more than $50 \mathrm{~cm}$ deep. The substrate was mostly bedrock. Crevices in the bedrock were filled with rubble and gravel and formed small riffles. Slab rocks lined the margins of the stream and formed small shallow pools. Most trees and shrubs had been removed and grasses covered the banks. During the study period water temperatures ranged from $8.5^{\circ}$ to $25^{\circ} \mathrm{C}$.

Wartrace Creek, at the Route 82 bridge, $2 \mathrm{~km}$ east of Bell Buckle, Bedford County, Tennessee (Fig. 2), is one of the few known localities at which $E$. striatulum is moderately common. During the study period the stream averaged about $16 \mathrm{~m}$ in width. The depth averaged about $30 \mathrm{~cm}$ and reached a maximum of $1.5 \mathrm{~m}$. Water temperatures varied from $2^{\circ}$ to $25^{\circ} \mathrm{C}$. The study area included one rubble riffle; the remainder consisted of a large pool above the riffle (Fig. 2). In the pool the substrate was mostly bedrock, but large expanses of gravel and, along the east bank, of silt were also present. Large flat stones were scattered over an area encompassing about one-fourth of the pool. Fishes encountered at the site, in approximate order of abundance, were Pimephales notatus, Etheostoma squamiceps, Notropis ardens, E. striatulum, N. boops, Lepomis megalotis, Etheostoma species (cf. simoterum), E. atripinne, E. luteovinctum, L. macrochirus, Gambusia affinis, E. caeruleum, E. fla- 


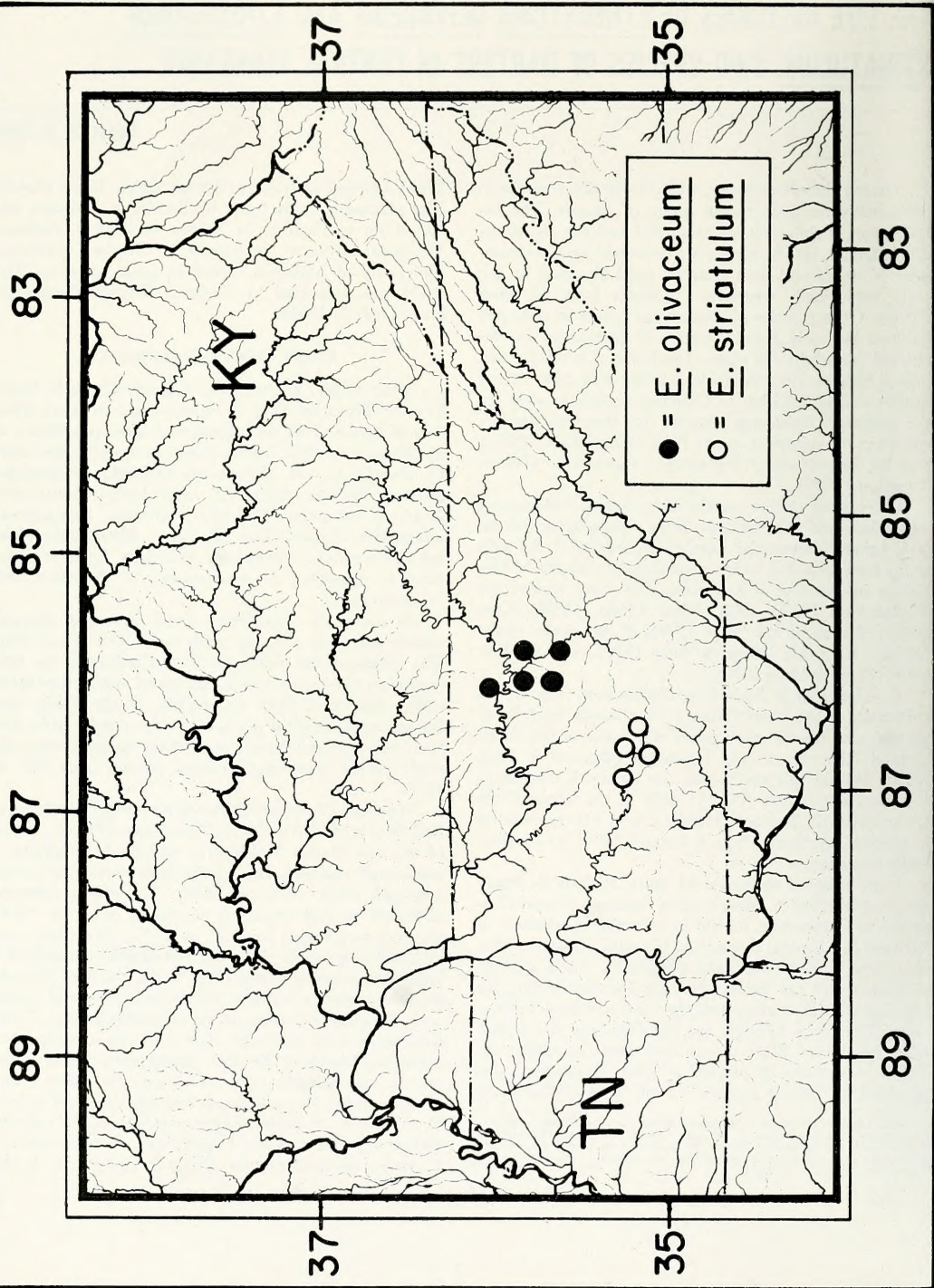



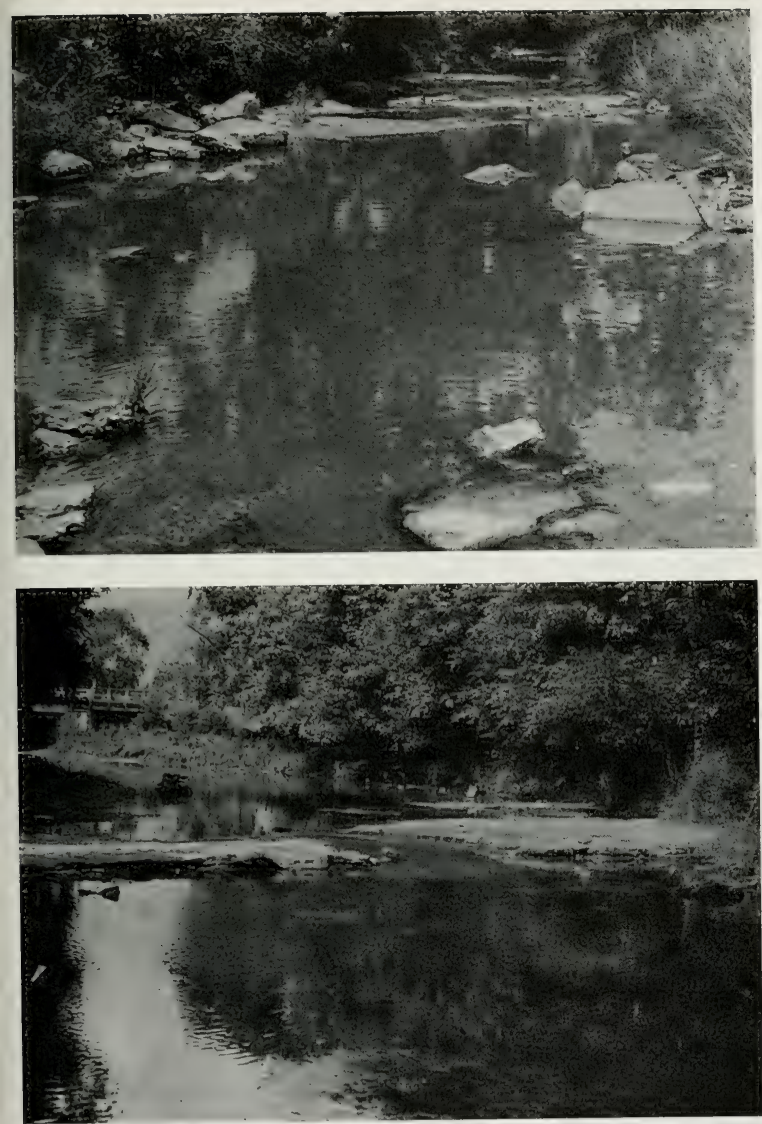

Fig. 2.-Top: Brush Creek study area, Smith County, Tennessee, 23 June 1977. Bottom: Wartrace Creek study area, Bedford County, Tennessee, 23 June 1977. bellare, L. cyanellus, Fundulus notatus, Ambloplites ruprestris, Cottus carolinae, Micropterus dolomieui, E. blennioides, $F$. catenatus, Semotilus atromaculatus, Moxostoma duquesnei, Ictalurus natalis, and Hypentelium nigricans.

Methods of study were the same as those used in the study of $E$. squamiceps (Page 1974:4-5) except that collections were made at about 2 -month rather than 1-month intervals; collections were recorded as having been taken from riffles, bedrock pools, or slab pools; fin and caudal peduncle measurements were not taken; and functual regressions of weight on standard length were computed following Ricker (1973). Studies were begun at both sites on 12 December 1976 and terminated on 30 January 1979. Totals of 471 E. olivaceum and 191 E. striatulum were preserved and examined. 


\section{HABITATS}

E. olivaceum inhabits only small (1st-and 2nd-order) streams and is not known from the mainstreams of either Caney Fork or the Cumberland River. In Brush Creek, young and adults were most common in slab-rock pools along the margins of the stream (Fig. 2); occasionally, they were found in riffles or bedrock pools.

E. striatulum inhabits small to moderate-sized streams: most individuals found have been in 2nd-order streams. In Wartrace Creek, most young and adults were captured by lifting large slab stones in water $0.1-1.0 \mathrm{~m}$ deep and kicking beneath the stone in the direction of a hand-held dipnet. No E. striatulum were captured in riffles and few were captured over open bedrock away from slab. A few small $E$. striatulum were captured by seining over gravel.

The affinities of $E$. olivaceum and of E. striatulum for slab pools were discussed by Page \& Schemske (1978). Both species utilize slab stones as cover throughout the year and as nesting sites during the spawning season.

\section{REPRODUCTION}

Genital papillae of both nonbreeding and breeding E. olivaceum and E. striatulum are essentially identical to those illustrated for other species of Catonotus (Page 1974:6, 1975a:4; Page \& Burr 1976:4).

Morphological descriptions, including those of breeding males, are given for E. olivaceum by Braasch \& Page (1979) and for E. striatulum by Page \& Braasch (1977). Females of both species undergo little (a few darken somewhat) or no color change prior to or during the breeding season and are essentially identical in color and pattern to nonbreeding females.

\section{Reproductive Cycle of the Male}

In March and April males of both species selected cavities under slab rocks and defended them as breeding territories. E. olivaceum males transferred to a 40 -gallon aquarium in March 1977 became territorial (about 2 weeks after the transfer) and combative. Some territorial males, especially when encountering other males, were pigmented similar to $E$. squamiceps as described and figured by Page (1974:6); i.e., the sides of the body were white anteriorly and dark posteriorly with black vertical bars. Other territorial males remained mottled brown with no conspicuous pattern but with a bold black humeral spot and bold bright eye.

In E. squamiceps, only males reaching $40 \mathrm{~mm}$ or more by the end of the spawning season developed breeding colors and had enlarged testes; smaller males, including most 1-year-olds, apparently did not spawn (Page 1974). Similarly, E. olivaceum males less than about $43 \mathrm{~mm}$ failed to have breeding colors and enlarged testes and probably did not spawn. Observations in Brush Creek indicated that large males held a proportion of nests greater than their proportion in the male population and, as in other species of Catonotus, the largest males presumably did most of the spawning (Page 1974: 7, 1975a:5; Page \& Burr 1976:5). Although in E. squamiceps there was no indication that 1 -year-old males spawned, many of the E. olivaceum males found guarding nests were large 1-year-olds.

All of the April-collected males of E. striatulum, including the smallest $(37 \mathrm{~mm}$ ), had developed breeding colors and enlarged testes and were potential spawners. All were 1 year old.

\section{Reproductive Cycle of the Female}

As in other darters, ova development in E. olivaceum and in E. striatulum progressed most rapidly in the largest females. Small white ova appeared in both species as early as October, yellow ova as early as February, and orange ova in March.

In $E$. olivaceum, the relationship between the mean of the weight of the ovaries divided by the adjusted body weight $(\mathrm{Y})$ and the month $(\mathrm{X})$, with June $=1$ and April $=11$, was $\log \mathrm{Y}=0.458+0.151 \mathrm{X}$, with $r$ $=0.981$ (Fig. 3). The proportionally largest ovaries (equalling 28.8 percent of the adjusted body weight) were found in a $40-\mathrm{mm}$ female collected on 16 April 1978. In E. striatulum, the relationship was $\log \mathrm{Y}=$ $0.352+0.103 \mathrm{X}$, with $r=0.812$ (Fig. 4). Although the ovaries of E. striatulum females failed to average heavier in March and April than in January and February (Fig. 4) they did contain maturing ova. The low numbers of mature ova in some of the females (Table 1) correspond to the low weights in March and April. The largest

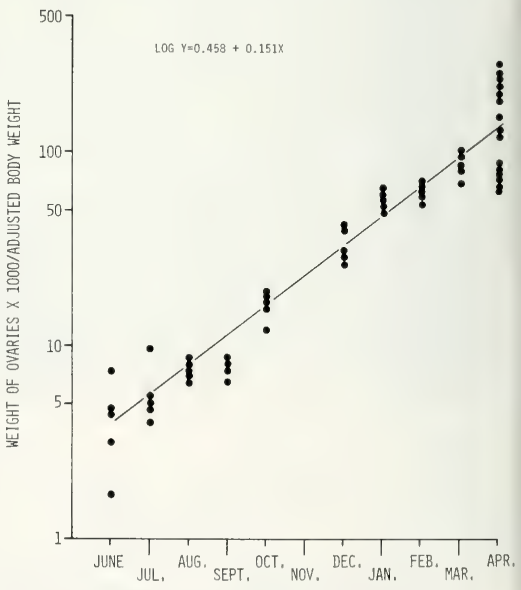

Fig. 3.-Monthly variations in ovarian weight relative to adjusted body weight of Etheostoma olivaceum. 
ovaries (26.8 percent) found in $E$. striatulum were in a 1-year-old, 37-mm female collected on 14 April 1978.

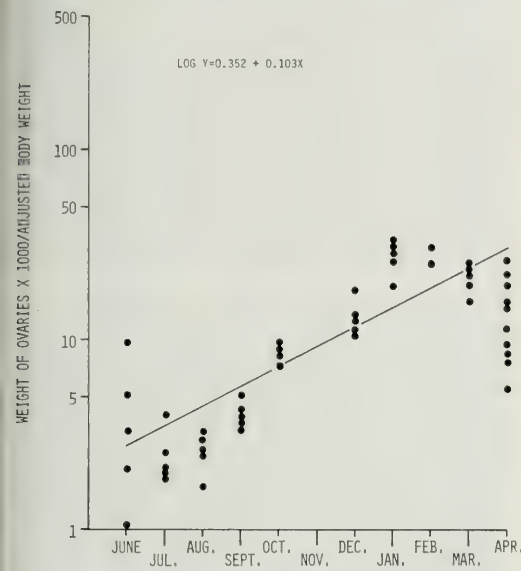

Fig. 4.-Monthly variations in ovarian weight relative to adjusted body weight of Etheostoma striatulum.

All April-collected females, including an E. olivaceum only $36 \mathrm{~mm}$ and an E. striatulum only $31 \mathrm{~mm}$ in length, contained mature ova and were potential spawners. In 9 ripe $E$. olivaceum the number of mature ova ranged from 60 to 112 , and in 10 ripe $E$. striatulum ranged from 19 to 108 (Table 1). For these females there was no significant correlation between the number of mature ova and the standard length, nor between the number of mature ova and the adjusted body weight; for both relationships correlation values were less than 0.42 for both species. The highest correlation $(r=0.417)$ was the relationship between the number of ova and standard length of $E$. striatulum. One of the reasons suggested for a lack of correlation between the size of the female and number of ova in E. procliare (Burr \& Page 1978:6-7) was that all females examined were 1 year old and about the same size at spawning; this is also true of the E. olivaceum and E. striatulum females (Table 1). In species of Catonotus for which significant correlations were found between the size of the female and the number of ova, there was greater variation in the size of the females examined (Page 1974:8, 1975a:5; Page \& Burr 1976:5).

In ripe females of both species, mature ova averaged about $1.8 \mathrm{~mm}$ in diameter, were translucent, had one or more large yellow oil droplets, and were indented on one side (Fig. 5). The indentation in the egg, previously described only for $E$. proeliare, $E$. fonticola, and $E$. microperca (Burr \& Page 1978, 1979), is apparently a more widespread phenomenon among darters than indicated in those descriptions and in Burr (1978). Why it was not observed in other studies involving mature eggs of darters is unknown, although the indentation is visible only on fully mature eggs and it may appear only a short time before spawning.

\section{Spawning}

Nests of E. olivaceum eggs were found on the undersides of stones, a tin can and a piece of tile in Brush

TABLE 1.-Relationship between size and ovary weight of Etheostoma olivaceum and $E$. striatulum females and the number of mature ova produced. All females were 12 months old.

\begin{tabular}{|c|c|c|c|}
\hline $\begin{array}{l}\text { Standard } \\
\text { Length } \\
\text { in mm }\end{array}$ & $\begin{array}{c}\text { Adjusted } \\
\text { Body Weight } \\
\text { in Grams" }\end{array}$ & $\begin{array}{c}\text { Ovary } \\
\text { Weight in } \\
\text { Grams }\end{array}$ & $\begin{array}{l}\text { Number } \\
\text { of Mature } \\
\text { (Orange or } \\
\text { Translu- } \\
\text { cent) Ova }\end{array}$ \\
\hline
\end{tabular}

E. olivaceum

$\begin{array}{rrrr}37 & 0.72 & 0.09 & 60 \\ 40 & 0.87 & 0.25 & 73 \\ 41 & 1.06 & 0.20 & 74 \\ 42 & 0.99 & 0.18 & 90 \\ 42 & 1.03 & 0.25 & 75 \\ 44 & 1.10 & 0.17 & 98 \\ 44 & 1.27 & 0.32 & 112 \\ 44 & 1.30 & 0.33 & 69 \\ 45 & 1.31 & 0.16 & 72\end{array}$

E. striatulum

$\begin{array}{rrrr}31 & 0.39 & 0.06 & 19 \\ 33 & 0.47 & 0.04 & 31 \\ 35 & 0.62 & 0.04 & 45 \\ 35 & 0.64 & 0.10 & 46 \\ 37 & 0.56 & 0.05 & 59 \\ 37 & 0.60 & 0.16 & 61 \\ 38 & 0.73 & 0.06 & 108 \\ 39 & 0.71 & 0.16 & 45 \\ 41 & 0.85 & 0.10 & 30 \\ 43 & 1.16 & 0.23 & 92\end{array}$

"Adjusted body weight is the specimen's weight after the removal of the ovaries, stomach, intestine, and liver.

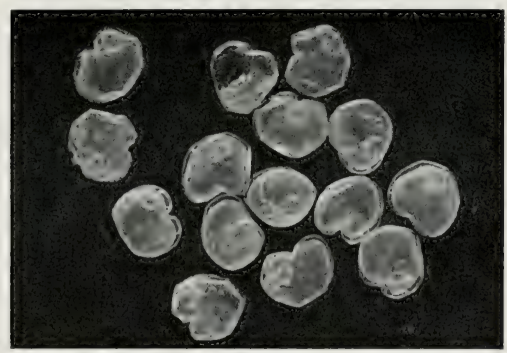

Fig. 5.- Fully mature eggs removed from an April-collected Etheostoma olivaceum. 

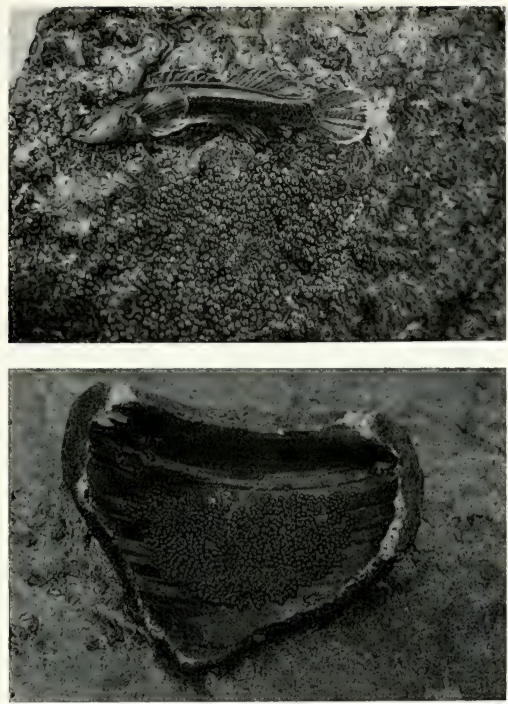
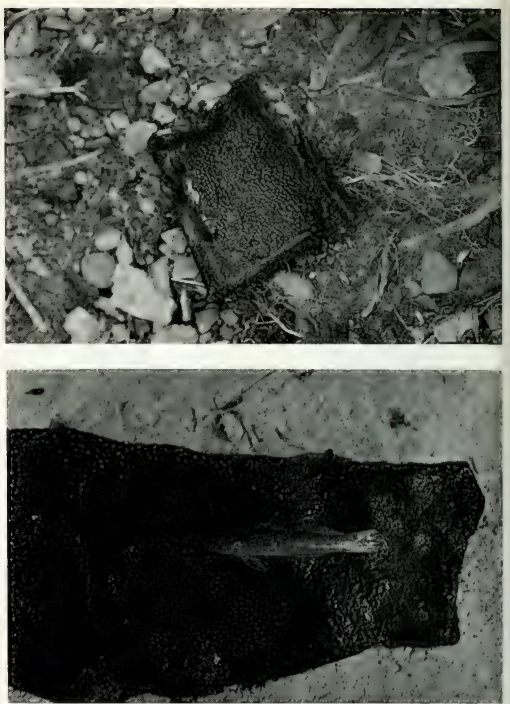

Fig. 6.-Nests of Etheostoma olivaceum removed from Brush Creek on 21 April 1977 and of E. striatulum removed from Wartrace Creek on 20 April 1977. Top left: E. olivaceum male and his nest of eggs on a stone. Top right: E. olivaceum eggs cn a flattened and partly disintegrated metal can. Bottom left: $E$. olivaceum eggs on a piece of tile. Bottom right: $E$. striatulum male and his nest of eggs on a stone. All nests were on the undersides of the objects shown when submerged.

Creek on 21 April 1977 (water temperature $=17^{\circ} \mathrm{C}$ ) and on 16 April $1978\left(19^{\circ} \mathrm{C}\right)$. Several spawning pairs were interrupted as stones were lifted in Brush Creek on 16 April 1978. No nests were found on 3 March $1977\left(9^{\circ}\right.$ C) or on 18 June 1977. The spawning period probably extends in most years from late March into May.

Counts and estimates of the numbers of eggs in 19 nests of E. olivaceum in Brush Creek were 107, 140, 200, $250,250,275,300,350,400,420,450,460,475,581,643$, $651,725,1050$, and $1500(\overline{\mathrm{X}}=486)$. Eggs in nests averaged $2 \mathrm{~mm}$ in diameter and were round and translucent.

Other species of Catonotus (E. squamiceps, E. kennicotti, E. smithi) spawned in aquaria when transferred from streams as ripe individuals (Page 1974:8, Page 1975a, 1975b; Page \& Burr 1976:6). E. olivaceum also was transferred to aquaria but generally remained too wary to spawn and only one spawning act was witnessed (on 18 April 1978 at $27^{\circ} \mathrm{C}$ ). The behavior observed during that one spawning act appeared to be identical to that of $E$. squamiceps, the closest relative of $E$. olivaceum. The female only briefly inverted to deposit eggs; in species of Catonotus other than E. squamiceps and $E$. olivaceum the female remains inverted for the duration of egg-laying, which may last for hours (Page $1975 b$ ).

Nests of E. striatulum eggs were found on the undersides of stones (Fig. 6) in Wartrace Creek on 20 April $1977\left(22^{\circ} \mathrm{C}\right)$ and on 14 April $1978\left(16^{\circ} \mathrm{C}\right)$ in water $10-45 \mathrm{~cm}$ deep. Counts and estimates of eggs in 11 nests were $25,25,47,98,130,180,190,210,225,250$, and $327(\overline{\mathrm{X}}=155)$. Eggs averaged $2 \mathrm{~mm}$ in diameter and were round and translucent. Because of the small samples of E. striatulum collected, no attempt was made to transport live individuals to spawning tanks. The behavior of the closely related E. smithi was described by Page \& Burr (1976:6).

The undersides of trash items were used as nesting sites by $E$. olivaceum in Brush Creek although most nests were on stones (Fig. 6). As in nests of other species of Catonotus, eggs of E. olivaceum and E. striatulum were packed closely in a concentrated area but were not laid on top of one another (an exception to this general rule was noted in E. neopterum - Page \& Mayden 1979 ). In one instance, two nests of $E$. olivaceum were found on one stone when lifted from the stream. The 
proximal margins of the nests were $15 \mathrm{~cm}$ apart and presumably when the stone was partially embedded in the stream bed the two guarding males were hidden from one another. In Wartrace Creek on 20 April 1977 and on 14 April 1978, nests of E. squamiceps were about three times as common as those of $E$. striatulum. One stone, measuring about $20 \times 30 \mathrm{~cm}$. was used simultaneously by $E$. striatulum and $E$. squamiceps. The margins of the two nests were about $8 \mathrm{~cm}$ apart; the centers of the nests were about $15 \mathrm{~cm}$ apart. Three nests of Pimephales notatus were also found on these two dates on the undersides of slab stones similar to those used by $E$. striatulum and $E$. squamiceps.

Males of E. olivaceum and of E. striatulum remain under their nest stones after spawning and guard the eggs until hatching.

\section{DEVELOPMENT AND GROWTH}

Nests of E. olivaceum eggs were transferred from Brush Creek to a laboratory aquarium and kept at $22^{\circ}$ $\pm 3^{\circ} \mathrm{C}$ until hatching. E. olivaceum hatchlings $0-22$ hours-old $(\mathrm{N}=8)$ averaged $6.6 \mathrm{~mm}$ in total length and, with well-developed jaws and pectoral fins (Fig. 7), were morphologically similar to other Catonotus hatchlings. Hatchlings were nearly translucent with few melanophores. Fin rays were present only in the incipient pectoral and caudal fins.

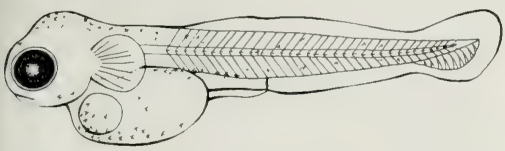

Fig. 7.-Etheostoma olicaceum hatchling $(7 \mathrm{~mm}$ total length).

On 18 June 197749 young $E$. olivaceum ranging from 15 to $28 \mathrm{~mm}$ were collected in the study area. Individuals shorter than $20 \mathrm{~mm}$ had prominent round spots along the midside and distinct dorsal blotches. On those longer than $20 \mathrm{~mm}$ the color pattern was mottled and essentially identical to that of the adult. On the smallest specimen $(15 \mathrm{~mm})$ the lateral line was present on only one scale, squamation was complete except on the nape and belly, and the infraorbital canal was nearly but not fully formed. On individuals $20 \mathrm{~mm}$ and longer, the lateral line extended to at least the origin of the first dorsal fin, squamation was complete, and the infraorbital canal was fully formed.

For $E$. olivaceum males the relationship between standard length $(\mathrm{Y})$ and age in months $(\mathrm{X})$ was $\mathrm{Y}=$ $7.1+35.67 \log \mathrm{X}$, with $r=0.877$, and for females was $\mathrm{Y}=11.1+29.92 \log \mathrm{X}$, with $r=0.829$ (Fig. 8). At 12 months males averaged $48.5 \mathrm{~mm}$ and were significantly $(t=4.06$, $\mathrm{df}=66$ ) longer than fermales (aver-

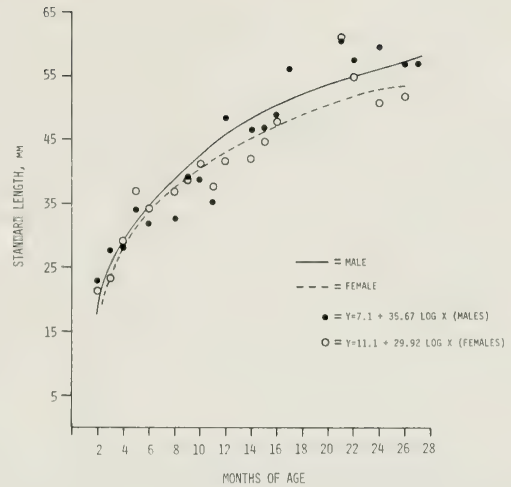

Fig. 8.-Size distribution by age of Etheostoma olivaceum collected in Brush Creek between 12 December 1976 and 30 January 1979. Black dots represent sample means for males: circles represent sample means for females. A total of 471 specimons is represented.

aging $41.8 \mathrm{~mm})$. One half of the first year's mean growth was reached in about 10 weeks; this is somewhat less time than that estimated (12-16 weeks) for other species of Catonotus (Page 1974:12, 1975a:9; Page \& Burr 1976:9). The largest specimen examined from Brush Creek was a $64.8-\mathrm{mm}$ male collected on 30 January 1979; the largest specimen of the species recorded is $67 \mathrm{~mm}$ (Braasch \& Page 1979).

For $E$. striatulum males the relationship between standard length $(\mathrm{Y})$ and age in months $(\mathrm{X})$ was $\mathrm{Y}=$ $11.2+26.32 \log \mathrm{X}$, with $r=0.881$, and for females was $\mathrm{Y}=14.6+20.00 \log \mathrm{X}$, with $r=0.798$ (Fig. 9). At 12 months, males, averaging $43.8 \mathrm{~mm}$, were significantly $(t=4.40, \mathrm{df}=20)$ longer than females, which averaged $37.0 \mathrm{~mm}$. As in E. olivaceum, one half of the first year's mean growth was reached in about 10 weeks. The largest specimen examined from Wartrace Creek, and the largest specimen of E. striatulum known, is a 48.7 mm male collected on 20 April 1977.

For $E$. olivaceum $(N=100)$ the functional regression (Ricker 1973) of weight (W) on standard length (L) was $\log \mathrm{W}=-4.142+2.591 \log \mathrm{L}$, with $r=$ 0.838 ; and for E. striatulum $(\mathrm{N}=82)$ was $\log \mathrm{W}=$ $-4.375+2.695 \log \mathrm{L}$, with $r=0.852$.

\section{DEMOGRAPHY}

\section{Density}

Density samples of E. olivaceum were taken in Brush Creek and of E. striatulum in Wartrace Creek by repeatedly seining an area until no more individuals were collected. On 10 August 1977 the density of $E$. 


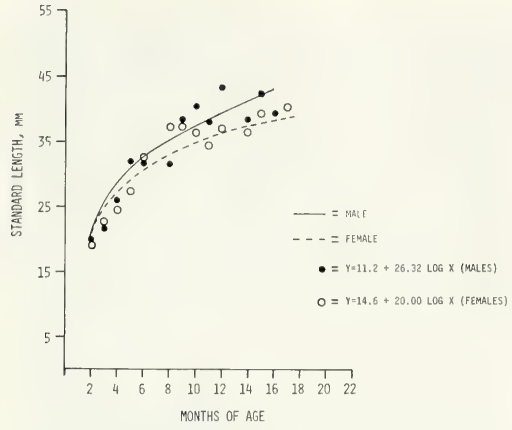

Fig. 9.-Size distribution by age of Etheostoma striatulum collected in Wartrace Creek between 12 December 1976 and 30 January 1979. Symbols as in Fig. 8. A total of 191 specimens is represented.

olivaceum in slab pools, the preferred habitat, was found to be 0.03 individuals per $\mathrm{m}^{2}$. On 30 January 1979 densities of $E$. olivaceum per $\mathrm{m}^{2}$ were: in slab pools, 0.07 ; in riffles, 0.02 ; in bedrock pools, 0.01 . On 30 January $1979,0.01 E$. striatulum per $\mathrm{m}^{2}$ were found in the slab-rock portion (about one-fourth) of the large pool constituting the study area.

\section{Composition}

Of the 471 E. olivaceum collected in Brush Creek between 12 December 1976 and 30 January 1979, 90.0 percent were up to 1 year of age, 9.1 percent were over 1 and up to 2 years, and 0.9 percent were over 2 years (Table 2). Sex ratios were skewed in favor of females in the first-year class ( 1.7 females to 1 male; $x^{2}=27.51$, $\mathrm{P}<0.005)$ and in the total sample $(1.6$ females to 1 male; $\left.\chi^{2}=28.08, \quad \mathrm{P}<0.005\right)$. Females have predominated in other Catonotus populations studied, with ratios varying from $1.2: 1$ to $1.7: 1$, as discussed by Page (1974:13, 1975a:10), Page \& Burr (1976:9), and Flynn \& Hoyt (1979:134).

Of the 191 E. striatulum collected in Wartrace Creek between 12 December 1976 and 30 January 1979, 94.8 percent were up to 1 year of age and 5.2 percent were between 1 and 2 years of age (Table 2). Unlike in other species of Catonotus, the sex ratio did not deviate significantly from $1: 1$.

\section{Survival}

Of the $178 \mathrm{E}$. olivaceum males collected, 88.8 percent were up to 1 year of age, 9.6 percent were over 1 and up to 2 years, and 1.7 percent were over 2 years. Of the 293 females, 90.8 percent were up to 1 year of age, 8.9 percent were over 1 and up to 2 years, and 0.3 percent were over 2 years. Only 10.8 percent of the first-year males and 9.8 percent of the first-year females (10.1 percent of the combined sexes) survived to a second year. Only 17.6 percent of the second-year males and 3.8 percent of the second-year females (9.3 percent with sexes combined) survived to a third year. The oldest $E$. olivaceum from Brush Creek (assuming an April hatching) was a 27-month-old male collected in July 1978.

Of the $87 \mathrm{E}$. striatulum males collected, 95.4 percent were up to 1 year of age and only 4.6 percent were over 1 year. Of the 104 females collected 94.2 percent were up to 1 year of age and 5.8 percent were over 1 year. Assuming each age class was collected in proportion to its relative number in the Wartrace Creek population, only 4.8 percent of the first-year males and 6.1 percent of the first-year females survived to a second year. The survival to a second year for males and females combined was 5.5 percent. Survival values for E. striatulum are lower than those found for other species of Catonotus (Page 1974:13-14, 1975a: 10-11; Page \& Burr 1976:9) but are similar to those for E. proeliare (Burr \& Page 1978:10-11). Both E. striatulum and E. proeliare are essentially annual fishes, with few individuals living beyond 1 year of age. The oldest $E$. striatulum from Wartrace Creek examined (assuming an April hatching) was a 17-month-old female collected in September 1978.

\section{Migration}

E. olivaceum and E. striatulum were found with relative ease at the study areas during every visit and no indication of any seasonal movements up or downstream or from one habitat to another was apparent.

TABLE 2.-Distribution of sexes and year classes in samples of Etheostoma olivaceum and E. striatulum collected between 12 December 1976 and 30 January 1979.

\begin{tabular}{|c|c|c|c|c|}
\hline \multirow{2}{*}{ Sex } & \multicolumn{3}{|c|}{ Number by Year Class } & \multirow{2}{*}{ Total } \\
\hline & + & $1+$ & $2+$ & \\
\hline \multicolumn{5}{|c|}{ E. striatulum } \\
\hline Male & 83 & 4 & $\cdots$ & 87 \\
\hline Female & 98 & 6 & $\ldots$ & 104 \\
\hline Total & 181 & 10 & $\ldots$ & 191 \\
\hline \multicolumn{5}{|c|}{ E. olivaceum } \\
\hline Male & 158 & 17 & 3 & 178 \\
\hline Female & 266 & 26 & 1 & 293 \\
\hline Total & 424 & 43 & 4 & 471 \\
\hline
\end{tabular}

Stomach contents of 72 E. olivaceum and $51 E$. striatulum were analyzed and tabulated by size class of darter (Tables 3 and 4) and by month of collection (Tables 5 and 6). For both species the diet consisted, as it has in almost all darters studied, mainly of aquatic insects and small crustaceans. Chironomid larvae were consumed in large numbers by all size classes (Tables 3 and 4). Small darters also fed heavily on microcrustaceans and large darters also fed on large insects (stone- 
TABLE 3.- Stomach contents of Etheostoma olivaceum from Brush Creek, by size class of darter. Figures in parentheses are numbers of stomachs examined.

\begin{tabular}{|c|c|c|c|c|c|c|c|c|c|c|}
\hline \multirow[b]{2}{*}{ Food Organism } & \multicolumn{5}{|c|}{$\begin{array}{l}\text { Percent of Stomachs in Which } \\
\text { Food Organism Occurred }\end{array}$} & \multicolumn{5}{|c|}{$\begin{array}{c}\text { Mean Number of Food Organisms } \\
\text { per Stomach }\end{array}$} \\
\hline & $\underset{(6)}{\operatorname{mm}}$ & $\begin{array}{l}21-30 \\
\mathrm{~mm} \\
(16)\end{array}$ & $\begin{array}{l}31-10 \\
\operatorname{mm} \\
(17)\end{array}$ & $\begin{array}{l}41-50 \\
\mathrm{~mm} \\
(17)\end{array}$ & $\begin{array}{l}>50 \\
\mathrm{~mm} \\
(16)\end{array}$ & $\begin{array}{c}<21 \\
\mathrm{~mm} \\
(6)\end{array}$ & $\begin{array}{l}21-30 \\
\mathrm{~mm} \\
(16)\end{array}$ & $\begin{array}{l}31-40 \\
\mathrm{~mm} \\
(17)\end{array}$ & $\begin{array}{c}41-50 \\
\mathrm{~mm} \\
(17)\end{array}$ & $\begin{array}{l}>50 \\
\mathrm{~mm} \\
(16)\end{array}$ \\
\hline Oligochaeta & $\ldots$ & 12.5 & $\ldots$ & $\ldots$ & 6.3 & $\ldots$ & 0.13 & $\ldots$ & $\ldots$ & 0.19 \\
\hline Gastropoda & $\ldots$ & $\ldots$ & 5.9 & $\ldots$ & $\ldots$ & $\ldots$ & $\ldots$ & 0.06 & $\ldots$ & $\ldots$ \\
\hline $\begin{array}{l}\text { Arachnida } \\
\text { Acarina }\end{array}$ & $\ldots$ & $\cdots$ & 11.8 & 5.9 & 6.3 & $\cdots$ & $\cdots$ & 0.18 & 0.71 & 0.13 \\
\hline $\begin{array}{l}\text { Crustacea } \\
\text { Cladocera } \\
\text { Ostracoda } \\
\text { Copepoda } \\
\text { Isopoda } \\
\text { Amphipoda }\end{array}$ & $\begin{array}{l}16.7 \\
16.7 \\
66.7 \\
\ldots \\
\ldots\end{array}$ & $\begin{array}{r}43.8 \\
6.3 \\
50.0 \\
6.3 \\
\ldots\end{array}$ & $\begin{array}{l}17.6 \\
23.5 \\
29.4 \\
\cdots \\
5.9\end{array}$ & $\begin{array}{c}\cdots \\
17.6 \\
11.8 \\
\ldots\end{array}$ & $\begin{array}{r}\cdots \\
\cdots \\
6.3 \\
12.5\end{array}$ & $\begin{array}{l}0.33 \\
0.17 \\
7.33 \\
\ldots \\
\ldots\end{array}$ & $\begin{array}{l}1.06 \\
0.06 \\
8.19 \\
0.06 \\
\ldots\end{array}$ & $\begin{array}{l}0.35 \\
0.29 \\
5.12 \\
\ldots .06\end{array}$ & $\begin{array}{l}\cdots \\
\cdots \\
0.24 \\
0.12 \\
\cdots\end{array}$ & $\begin{array}{l}\cdots \\
\cdots \\
0.06 \\
0.13\end{array}$ \\
\hline $\begin{array}{l}\text { Insecta } \\
\text { Plecoptera } \\
\text { Ephemeroptera } \\
\text { Hemiptera }\end{array}$ & $\ddot{16.7}$ & $\ddot{2} \ddot{0} .0$ & $\begin{array}{r}5.9 \\
23.5\end{array}$ & $\begin{array}{r}5.9 \\
47.1\end{array}$ & $\begin{array}{r}6.3 \\
31.3\end{array}$ & $\ddot{0.17}$ & $\ddot{0} 31$ & $\begin{array}{l}0.12 \\
0.24\end{array}$ & $\begin{array}{l}0.06 \\
0.59\end{array}$ & $\begin{array}{l}0.06 \\
0.75\end{array}$ \\
\hline $\begin{array}{l}\text { Gerridae } \\
\text { Trichoptera } \\
\text { Coleoptera }\end{array}$ & $\begin{array}{l}\cdots \\
\cdots\end{array}$ & $\begin{array}{l}\cdots \\
\cdots\end{array}$ & $\ddot{5.9}$ & $\begin{array}{r}5.9 \\
11.8\end{array}$ & $\ddot{12.5}$ & $\begin{array}{l}\cdots \\
\cdots\end{array}$ & $\begin{array}{l}\cdots \\
\cdots\end{array}$ & $\ddot{0} 0 \dot{0}$ & $\begin{array}{l}0.06 \\
0.12\end{array}$ & 0.13 \\
\hline $\begin{array}{l}\text { Dytiscidae } \\
\text { Elmidae } \\
\text { Others }\end{array}$ & $\begin{array}{l}\cdots \\
\cdots \\
\cdots\end{array}$ & $\begin{array}{l}\cdots \\
\cdots \\
\cdots\end{array}$ & $\begin{array}{r}11.8 \\
\ddot{11.8}\end{array}$ & $\begin{array}{l}3.9 \\
\cdots\end{array}$ & $\begin{array}{l}\cdots \\
\cdots \\
\cdots\end{array}$ & $\begin{array}{l}\cdots \\
\cdots \\
\cdots\end{array}$ & $\begin{array}{l}\cdots \\
\cdots \\
\cdots\end{array}$ & $\begin{array}{l}0.12 \\
\ldots .23\end{array}$ & 0.06 & $\begin{array}{l}\cdots \\
\cdots \\
\cdots\end{array}$ \\
\hline $\begin{array}{l}\text { Diptera } \\
\text { Tipulidae } \\
\text { Simuliidae } \\
\text { Chironomidae } \\
\text { Others }\end{array}$ & 100.0 & $\begin{array}{l}\cdots \\
37.5 \\
12.5\end{array}$ & $\begin{array}{r}3.9 \\
100.0 \\
5.9\end{array}$ & $\begin{array}{r}11.8 \\
11.8 \\
100.0 \\
5.9\end{array}$ & $\begin{array}{r}\ldots .3 \\
62.5 \\
\ldots\end{array}$ & $\begin{array}{c}\ldots \\
11.17 \\
\ldots\end{array}$ & $\begin{array}{c}\cdots \\
3.31 \\
0.19\end{array}$ & $\begin{array}{r}\ldots .06 \\
13.94 \\
0.06\end{array}$ & $\begin{array}{r}0.12 \\
0.29 \\
16.12 \\
0.12\end{array}$ & $\begin{array}{c}0.19 \\
7.88 \\
\ldots\end{array}$ \\
\hline
\end{tabular}

flies and caddisflies). Mayflies were ingested rather frequently by all sizes of $E$. olivaceum and by $E$. striatulum greater than $21 \mathrm{~mm}$.

For both species food consumption was heaviest in March, just before the spawning period (Tables 5 and $6)$.

\section{PREDATION AND PARASITISM}

Few potential predators were captured at either study site. At Brush Creek, four Cottus carolinae (66-105 mm) and one Lepomis macrochirus $(87 \mathrm{~mm}$ ) were preserved and later examined: none contained fish remains in its stomach or gut. At Wartrace Creek two Cottus carolinae (48-90 $\mathrm{mm})$, one Micropterus dolomieui $(90 \mathrm{~mm})$, and one Lepomis megalotis $(63 \mathrm{~mm})$ were examined. The only ingested fish was a $40-\mathrm{mm}$ Campostoma anomalum in the stomach of the $90-\mathrm{mm} C$. carolinae.

In the 72 stomachs of $E$. olivaceum examined, 8

TABLE 4,-Stomach contents of Etheostoma striatulum from Wartrace Creek, by size class of darter. Figures in parentheses are numbers of stomachs examined.

\begin{tabular}{|c|c|c|c|c|c|c|c|c|}
\hline \multirow[b]{2}{*}{ Food Organism } & \multicolumn{4}{|c|}{$\begin{array}{l}\text { Percent of Stomachs in Which } \\
\text { Food Organism Occurred }\end{array}$} & \multicolumn{4}{|c|}{$\begin{array}{l}\text { Mean Number of Food Organisms } \\
\text { per Stomach }\end{array}$} \\
\hline & $\begin{array}{c}<21 \\
\operatorname{mm} \\
(6)\end{array}$ & $\begin{array}{c}21-30 \\
\mathrm{~mm} \\
(16)\end{array}$ & $\begin{array}{c}31-40 \\
\operatorname{mm} \\
(16)\end{array}$ & $\begin{array}{l}>40 \\
\mathrm{~mm} \\
(13)\end{array}$ & $\underset{\substack{<m \\
(6)}}{<21}$ & $\begin{array}{c}21-30 \\
\operatorname{mm} \\
(16)\end{array}$ & $\begin{array}{c}31-40 \\
\operatorname{mm} \\
(16)\end{array}$ & $\begin{array}{l}>40 \\
\mathrm{~mm} \\
(13)\end{array}$ \\
\hline \multicolumn{9}{|l|}{ Crustacea } \\
\hline Cladocera & 66.7 & 31.3 & 12.5 & $\ldots$ & 1.17 & 0.44 & 0.13 & $\ldots$ \\
\hline Ostracoda & 50.0 & 6.3 & 18.8 & $\ldots$ & 0.50 & 0.06 & 0.19 & $\ldots$ \\
\hline Copepoda & 100.0 & 68.8 & 31.3 & 53.8 & 9.33 & 3.06 & 0.69 & 1.38 \\
\hline \multicolumn{9}{|l|}{ Insecta } \\
\hline Plecoptera & $\ldots$ & 12.5 & 6.3 & 15.4 & $\ldots$ & 0.13 & 0.06 & 0.16 \\
\hline Ephemeroptera & $\ldots$ & 12.5 & 6.3 & 7.7 & $\ldots$ & 0.19 & 0.06 & 0.08 \\
\hline Trichoptera & $\ldots$ & $\ldots$ & 6.3 & $\ldots$ & $\ldots$ & $\ldots$ & 0.06 & $\ldots$ \\
\hline \multicolumn{9}{|l|}{ Diptera } \\
\hline Simuliidae & $\ldots$ & 6.3 & $\ldots$ & $\ldots$ & $\cdots$ & 0.06 & $\cdots$ & $\ldots$ \\
\hline Chironomidae & 66.7 & 87.5 & 100.0 & 69.2 & 1.17 & 7.63 & 10.38 & 14.61 \\
\hline Others & ... & 6.3 & 6.3 & 7.7 & $\ldots$ & 0.06 & 0.06 & 0.08 \\
\hline
\end{tabular}




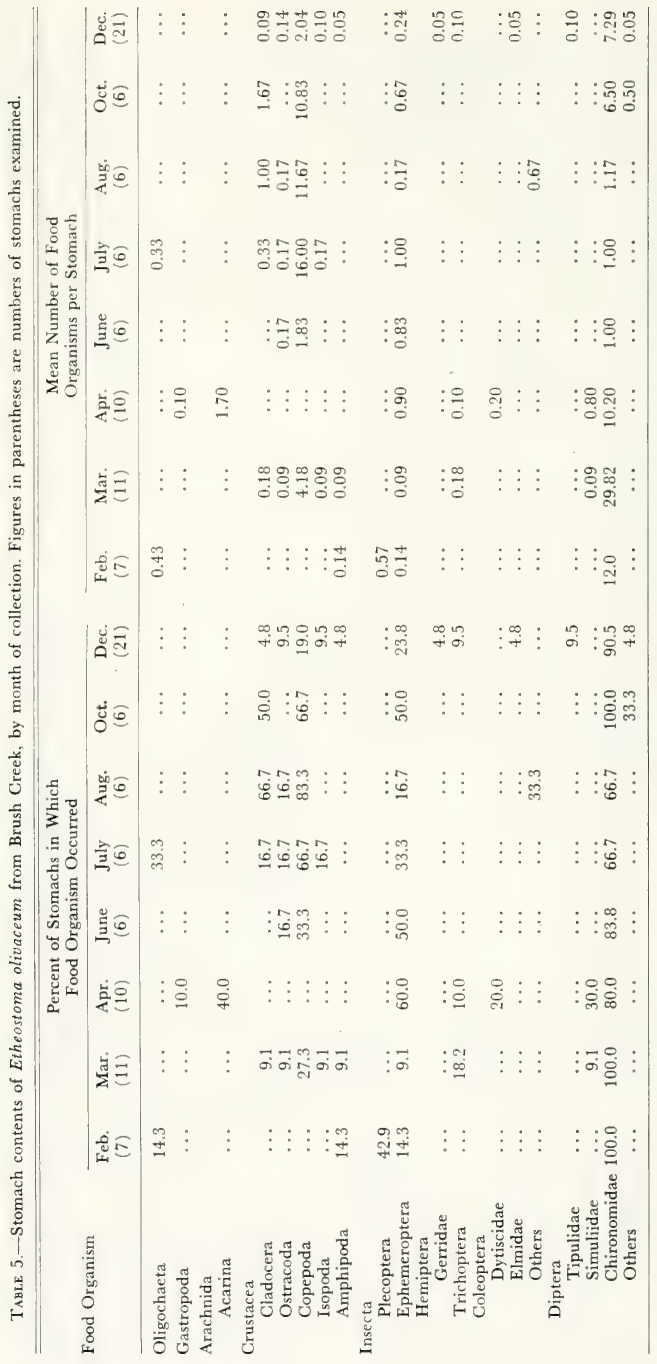


TABLE 6.-Stomach contents of Etheostoma striatulum from Wartrace Creek, by month of collection. Figures in parentheses are numbers of stomachs examined.

\begin{tabular}{|c|c|c|c|c|c|c|c|c|c|c|c|c|c|c|c|c|}
\hline \multirow{2}{*}{ Food Organism } & \multicolumn{8}{|c|}{$\begin{array}{l}\text { Percent of Stomachs in Which } \\
\text { Food Organisms Occurred }\end{array}$} & \multicolumn{8}{|c|}{$\begin{array}{l}\text { Mean Number of Food } \\
\text { Organisms per Stomach }\end{array}$} \\
\hline & $\begin{array}{l}\text { Feb. } \\
(4)\end{array}$ & $\begin{array}{l}\text { Mar. } \\
(10)\end{array}$ & $\begin{array}{l}\text { Apr. } \\
(8)\end{array}$ & $\begin{array}{c}\text { June } \\
(6)\end{array}$ & $\begin{array}{l}\text { July } \\
(6)\end{array}$ & $\begin{array}{l}\text { Aug. } \\
(6)\end{array}$ & $\begin{array}{l}\text { Oct. } \\
(4)\end{array}$ & $\begin{array}{c}\text { Dec. } \\
(7)\end{array}$ & $\begin{array}{l}\text { Feb. } \\
(4)\end{array}$ & $\begin{array}{l}\text { Mar. } \\
(10)\end{array}$ & $\begin{array}{l}\text { Apr. } \\
(8)\end{array}$ & $\begin{array}{l}\text { June } \\
(6)\end{array}$ & $\begin{array}{l}\text { July } \\
(6)\end{array}$ & Aug. & $\begin{array}{l}\text { Oct. } \\
(4)\end{array}$ & $\begin{array}{l}\text { Dec. } \\
(7)\end{array}$ \\
\hline \multicolumn{17}{|l|}{ Crustacea } \\
\hline Cladocera & $\ldots$ & $\ldots$ & 12.5 & 50.0 & 50.0 & 16.7 & 50.0 & 14.3 & $\ldots$ & $\ldots$ & 0.13 & 0.83 & 0.83 & 0.17 & 0.50 & 0.29 \\
\hline Ostracoda & $\ldots$ & 10.0 & 12.5 & 33.3 & 16.7 & $\ldots$ & $\ldots$ & 28. & & 0.10 & 0.13 & 0.33 & 0.17 & $\ldots$ & $\ldots$ & 0.29 \\
\hline Copepoda & 25.0 & 70.0 & 37.5 & 100.0 & 100.0 & 33.3 & 25.0 & 42.9 & 0.25 & 1.40 & 1.13 & 6.67 & 10.00 & 0.67 & 0.25 & 0.57 \\
\hline \multicolumn{17}{|l|}{ Insecta } \\
\hline Plecoptera & 25.0 & $\ldots$ & $\ldots$ & $\ldots$ & 50.0 & 16.7 & $\ldots$ & $\ldots$ & 0.25 & $\ldots$ & $\ldots$ & $\ldots$ & 0.50 & 0.17 & $\ldots$ & $\ldots$ \\
\hline Ephemeroptera & $\ldots$ & 20.0 & $\cdots$ & $\cdots$ & 16.7 & $\ldots$ & $\ldots$ & 14.3 & $\ldots$ & 0.20 & $\ldots$ & $\ldots$ & 0.33 & $\ldots$ & $\ldots$ & 0.14 \\
\hline $\begin{array}{l}\text { Trichoptera } \\
\text { Diptera }\end{array}$ & $\ldots$ & $\ldots$ & 12.5 & $\cdots$ & $\ldots$ & $\ldots$ & $\ldots$ & $\ldots$ & $\cdots$ & $\ldots$ & 0.13 & $\cdots$ & $\ldots$ & $\cdots$ & .. & .. \\
\hline Simuliidae & & & & & & & 25.0 & & & & & & & & 0.25 & \\
\hline Chironomidae & 100.0 & 100.0 & 75.0 & 66.7 & 66.7 & 83.3 & 100.0 & 85.7 & 3.50 & 36.90 & 1.88 & 4.16 & 0.83 & 2.17 & 1.75 & 5.25 \\
\hline Others & .. & $\ldots$ & $\ldots$ & ... & 16.7 & 33.3 & $\ldots$ & $\ldots$ & $\ldots$ & ... & $\ldots$ & $\ldots$ & 0.17 & 0.33 & $\ldots$ & ... \\
\hline
\end{tabular}

contained a total of 22 spinyheaded worms (Acanthocephalus). No parasitic worms were found in E. striatulum.

The most common external parasites, on 19 of 471 E. olivaceum and 17 of 191 E. striatulum, were fluke metacercariae. The metacercariae were found in almost all months in which collections were made. Parasitic copepods (Lernaea) were found on three E. striatulum collected in August.

\section{CONSERVATION OF E. STRIATULUM}

E. striatulum is known from fewer than a dozen localities, all in the Duck River system of Bedford, Marshall and Maury counties, Tennessee. It is moderately common in Wartrace Creek at the Route 82 bridge in Bedford County and at one or two other sites but is uncommon elsewhere. Although $E$. striatulum may never have been abundant, most present populations are small. The small populations and the low survival rate found at Wartrace Creek indicate that perpetuation of the species is uncertain.

Perpetuation of E. striatulum depends on the preservation of the natural characteristics of streams within its range. No historical data on fish populations are available for comparison; however, much of the land in Bedford and Marshall counties is farmland and streams in these counties probably are more heavily silted now than in the past and are reduced in size due to the loss of water being diverted to agricultural use. The streams in which E. striatulum occurs, especially Wartrace Creek with its relatively large population of $E$. striatulum, should be spared from further modifications.

TABLE 7.- Summary of life history information on Etheostoma olivaceum in Brush Creek and E. striatulum in Wartrace Creek.

\begin{tabular}{|c|c|c|}
\hline Characteristic & E. olivaceum & E. striatulum \\
\hline Principal habitat & Slab pools & Slab pools \\
\hline Age at reaching sexual maturity & 1 year & 1 year \\
\hline Age at first spawning & 1 year & 1 year \\
\hline Size at reaching sexual maturity & Females ahout $35 \mathrm{~mm}$ : males about $40 \mathrm{~mm}$ & Females about $30 \mathrm{~mm}$ : males about $35 \mathrm{~mm}$ \\
\hline Sexual dimorphism & $\begin{array}{l}\text { Males are larger and, in spring, are much } \\
\text { darker }\end{array}$ & Males are larger and more colorful \\
\hline Number of mature ova counted & $60-112$ & $19-108$ \\
\hline Description of egg in nest & $2.0 \mathrm{~mm}$ in diameter, translucent and round & $2.0 \mathrm{~mm}$ in diameter, translucent and round \\
\hline Spawning period & From late March into May & From late March into May \\
\hline Spawning habitat & Slab pools & Slab pools \\
\hline Spawning position & $\begin{array}{l}\text { Both male and female briefly inverted (one } \\
\text { observation) }\end{array}$ & Unknown \\
\hline Egg deposition site & Undersides of stones & Undersides of stones \\
\hline Number of eggs counted in nests & $107-1500$ & $25-327$ \\
\hline Egg guarding & Only by the male & Only by the male \\
\hline Influence of sex on growth rate & $\begin{array}{l}\text { At } 1 \text { year males are significantly larger than } \\
\text { females }\end{array}$ & $\begin{array}{l}\text { At i year males are significantly larger than } \\
\text { females }\end{array}$ \\
\hline Sex ratio among young & 1.7 females: 1 male & 1.2 females: 1 male \\
\hline $\begin{array}{l}\text { Longevity } \\
\text { Maximum size }\end{array}$ & $\begin{array}{l}27 \text { months } \\
65 \mathrm{~mm}\end{array}$ & $\begin{array}{l}17 \text { months } \\
49 \mathrm{~mm}\end{array}$ \\
\hline & $\begin{array}{l}65 \mathrm{~mm} \\
\text { None }\end{array}$ & None \\
\hline Territoriality & Extreme in breeding males & Extreme in breeding males \\
\hline Principal diet & Aquatic insect immatures and crustaceans & Aquatic insect immatures and crustaceans \\
\hline
\end{tabular}




\section{LITERATURE CITED}

ATz, J. W. 1940. Reproductive behavior in the eastern johnny darter, Boleosoma nigrum olmstedi (Storer). Copeia 1940 (2) :100-106.

BraAsch, M. E., and L. M. Page. 1979. Systematic studies of darters of the subgenus Catonotus (Percidae), with the description of a new species from Caney Fork, Tennessee. University of Kansas Museum of Natural History Occasional Papers 78, $10 \mathrm{p}$.

Burr, B. M. 1978. Systematics of the percid fishes of the subgenus Microperca, genus Etheostoma. Bulletin of the Alabama Museum of Natural History 4. 53 p. - and L. M. PAge. 1978. The life history of the cypress darter, Etheostoma proeliare, in Max Creek, Illinois. Illinois Natural History Survey Biological Notes 106.15 p.

, and 1979. The life history of the least darter, Etheostoma microperca, in the Iroquois River, Illinois. Illinois Natural History Survey Biological Notes $112.16 \mathrm{p}$.

FLynn, R. B, and R. D. Hoyт, 1979. The life history of the teardrop darter, Etheostoma barbouri Kuehne and Small. American Midland Naturalist 101 (1):127-141.

KarR, J. R. 1964. Age, growth, fecundity and food habits of fantail darters in Boone County, Iowa. Iowa Academy of Science Proceedings 71:274-280.

LAKE, C. T. 1936. The life history of the fan-tailed darter Catonotus fabellaris flabellaris (Rafinesque). American Midland Naturalist $17(5): 816-830$.

PAge, L. M. 1974. The life history of the spottail darter, Etheostoma squamiceps, in Big Creek, Illinois, and Ferguson Creek, Kentucky. Illinois Natural History Survey Biological Notes 89.20 p. . 1975a. The life history of the stripetail darter, Etheo- stoma kennicotti, in Big Creek, Illinois. Illinois Natural History Survey Biological Notes 93, 15 p.

. 1975b. Relations among the darters of the subgenus Catonotus of Etheostoma. Copeia 1975 (4):782-784.

- and M. E. BraAsch. 1977. Systematic studies of darters of the subgenus Catonotus (Percidae), with the description of a new species from the Duck River system. University of Kansas Museum of Natural History Occasional Papers 63. $18 \mathrm{p}$.

- and B. M. Burr, 1976. The life history of the slabrock darter, Etheostoma smithi, in Ferguson Creek, Kentucky. Illinois Natural History Survey Biological Notes 99. 12 p. , and R. L. MAYden, 1979. Nesting site of the lollypop darter, Etheostoma neopterum. Kentucky Academy of Sciences Transactions $40(1-2): 56-57$.

and D. W. Schemske. 1978. The effect of interspecific competition on the distribution and size of darters of the subgenus Catonotus (Percidae:Etheostoma). Copeia 1978 (3) : $406-412$.

Raney, E. C., and E. A. Lachner, 1939. Observations on the life history of the spotted darter, Poecilichthys maculatus (Kirtland), Copeia 1939(3):157-165.

Ricker, W. E. 1973. Linear regressions in fishery research. Canadian Fisheries Research Board Journal 30 (3):409-434.

WINN, H. E. 1958a. Observations on the reproductive habits of darters (Pisces-Percidae). American Midland Naturalist $59(1): 190-212$.

- 1958b. Comparative reproductive behavior and ecology of fourteen species of darters (Pisces-Percidae). Ecological Monographs 28(2):155-191. 


